\title{
O MEIO AMBIENTE TRATADO PELOS SELOS POSTAIS BRASILEIROS: UMA FERRAMENTA ADICIONAL PARA O ENSINO ENVOLVENDO ESTUDANTES E A BIODIVERSIDADE
}

\author{
Júlio César Penereiro ${ }^{1}$ \\ Denise Helena Lombardo Ferreira ${ }^{2}$ \\ Monica Cristina Meschiatti ${ }^{3}$
}

\begin{abstract}
Resumo: Este artigo propõe que é possível divulgar e ensinar aspectos relacionados ao Meio Ambiente por meio das imagens contidas nos selos postais. Foi realizado um levantamento que usa os selos postais brasileiros emitidos entre 1843 e 2013, de forma que o material filatélico analisado possibilitou revelar o papel cultural e o desenvolvimento das emissões abordando as diferentes modalidades de estudos relacionados ao Meio Ambiente. Propõe-se que esse material possa ser usado para sensibilizar a sociedade sobre a importância das pesquisas científicas e em trabalhos a serem desenvolvidos sobre as questões ambientais, além de ser uma ferramenta útil para o ensino e aprendizagem de assuntos abordados em disciplinas dos cursos de Engenharias, Biologia, Geografia, Ecologia, dentre outros. Os resultados obtidos revelam que a filatelia brasileira está cumprindo um importante papel, o de divulgar as diferentes áreas da ciência do Meio Ambiente.
\end{abstract}

Palavras-chave: Educação ambiental; Biodiversidade; Questões ambientais; Filatelia brasileira.

\footnotetext{
${ }^{1}$ Pontifícia Universidade Católica de Campinas (PUC-Campinas). E-mail: jcp@puc-campinas.edu.br

${ }^{2}$ Pontifícia Universidade Católica de Campinas (PUC-Campinas).

E-mail: lombardo@puc-campinas.edu.br.

${ }^{3}$ Instituto Agronômico (IAC). E-mail: monicameschiatti@hotmail.com.

Revbea, São Paulo, V. 10, N 1: 97-117, 2015.
} 


\section{Introdução}

A Educação Ambiental, como componente essencial no processo de formação e educação permanente, contempla uma abordagem direcionada à resolução de problemas sociais e econômicos, podendo contribuir para o envolvimento ativo do cidadão. Além disso, ela pode tornar o sistema educativo mais relevante e realista, estabelecendo uma maior interdependência entre a educação e o ambiente natural e social, beneficiando o bem estar de todos os envolvidos.

Se existem vários problemas que dizem respeito ao Meio Ambiente, isto se devem em parte ao fato das pessoas não serem sensibilizadas o suficiente para a compreensão do frágil equilíbrio da biosfera e dos problemas de gestão dos recursos naturais. Talvez isso ainda esteja ocorrendo porque essas pessoas não estão ou não foram preparadas para delimitar e resolver de uma maneira eficaz os problemas concretos existentes ao redor do ambiente imediato em que vivem, visto que a educação para o ambiente como abordagem didática ou pedagógica, apenas apareceu nos currículos escolares a partir década de 1980. Presume-se que somente depois desta época é que os estudantes tiveram oportunidade de tomar consciência das situações que acarretam problemas no meio em que vivem ou na biosfera em geral, refletindo sobre as suas causas e, como consequência, determinando os meios ou ações apropriadas na tentativa de amenizá-los ou resolvê-los. Certamente, isso não vem ocorrendo apenas nas escolas, pois os meios de comunicações em muito vem contribuindo para esclarecer e conscientizar a sociedade dos problemas ambientais contemporâneos.

Porém, era necessário criar formas estratégicas para enfrentar as problemáticas ambientais. Perante a essa consignação de necessidades, as Diretrizes Curriculares Nacionais para o Ensino Médio (DCNEM), assim como os Parâmetros Curriculares Nacionais do Ensino Médio (PCNEM), que foram apresentados em 1999-2000, enfatizaram propostas de orientação para os programas da educação no nível fundamental e médio, contendo textos referentes aos chamados temas transversais do ensino. Além das DCNEM e dos PCNEM, os denominados PCNEM+ produzidos em 2004, voltados à Ciência da Natureza, Matemática e suas Tecnologias, trazem orientações complementares àquele primeiro documento, no sentido de ajudar o professor a selecionar os conteúdos e a realizar opções metodológicas em suas atividades. Sugerem temas estruturadores das disciplinas a serem ensinadas, considerando a necessária integração com outras disciplinas, não só da mesma área, como também as outras que envolvem a linguagem e o código das ciências humanas (BRASIL, 2004). Um dos temas considerado de grande relevância é justamente a questão ambiental, cuja preocupação está voltada em construir cidadãos plenamente reconhecidos e conscientes de seu papel na sociedade. Neste sentido, os PCNEM+ destacam que: 
Cabe ressaltar, também, que as abordagens dos conteúdos precisam, obrigatoriamente, em algum momento do processo, estar articuladas, no âmbito do currículo escolar, de forma não fragmentada e não prescritiva com o desenvolvimento da educação ambiental, conforme preceitua o Plano Nacional de Educação. Pode-se trabalhar, a partir de temas como poluição, recursos energéticos, saúde, cosméticos, plásticos, metais, lixo, química agrícola, energia nuclear, petróleo, alimentos, medicamentos, agrotóxicos (Plano Nacional de Educação PNE, BRASIL, 2000): a educação ambiental, tratada como tema transversal, será desenvolvida como uma prática educativa integrada, contínua e permanente (BRASIL, 2004, p.122-123).

Entretanto, o que muitas vezes ocorre na Educação Ambiental é um contexto de desfragmentação dos saberes e do conhecimento descontextualizado que não possibilita uma visão da integração dos fatores sociais, econômicos, culturais e políticos que envolvem as questões ambientais, além da falta de valores éticos como, por exemplo, a cooperação, a responsabilidade sobre a qualidade das relações humanas e do Meio Ambiente que é necessário deixar para as gerações futuras.

Portanto, esse novo paradigma deve ser incorporado às Ciências, para promover a construção de novos valores, os quais possam conduzir a uma nova perspectiva, a do desenvolvimento que leve à sustentabilidade, cujo conceito surge como alternativa de enfrentamento da crise sócio ambiental, tendo em vista que a considera em sua totalidade e complexidade.

Neste sentido, a Filatelia, que é considerada como o "estudo dos selos do correio que se usam nas diferentes nações, metodicamente colecionados" (FERREIRA, 1999), pode perfeitamente colaborar e estimular as pessoas preocupadas com as questões do ensino e aprendizagem. Atualmente, se reconhece que os selos postais, principalmente os comemorativos emitidos por vários países ao longo dos anos, podem trazer em suas estampas diferentes mensagens com conotações históricas, sociais, culturais, econômicas, tecnológicas, geopolíticas e ambientais. Assim, esse tipo de material constitui um importante meio de comunicação dos valores de uma determinada sociedade (FONSECA, 2008).

Não obstante, com o advento do selo postal foi possível proporcionar uma racionalidade do sistema postal mundial. A disseminação desse artefato fez com que seu uso fosse visto como um eficaz meio de comunicação de massa, divulgando e popularizando conhecimentos de diversas áreas (CASTRO; DINIZ; BARROS, 2007; SALCEDO, 2010). Dentre essas áreas se podem incluir as Engenharias, Biologia, Geografia, Artes, Física, História, entre outras. Assim, é possível usar esse tipo de material como apoio ao ensino e aprendizagem de disciplinas vinculadas a essas áreas nos diferentes níveis de ensino. Como, em parte, destaca Maria Cecília Micotti, "[...] uma das principais funções da educação escolar é a de assegurar a propagação do saber" 
(MICOTTI, 1999, p.156), não apenas o saber específico, mas também o saber cultural.

É neste contexto que o presente trabalho se alia, isto é, se busca realizar algumas análises por meio de um amplo levantamento nos selos postais emitido pela Empresa Brasileira de Correios e Telégrafos, nos mais variados contextos relacionados ao Meio Ambiente. A pesquisa levou em consideração catálogos e diferentes endereços eletrônicos disponíveis na Internet. Optou-se por explorar os diversos segmentos envolvendo a temática ambiental visto que não existe, até a presente data (janeiro/2014), nenhuma publicação nessa área voltada ao estudo dos selos postais brasileiros. Aliado a isso, o trabalho aqui elaborado tem como pretensão incentivar e estimular a cultura da leitura e a realização de pesquisas na área do ensino do Meio Ambiente, permitindo vivenciar a produção do conhecimento e a evolução das ciências ambientais (Biologia, Engenharias, Geografia, Ecologia, dentre outras), ao empregar um material de uso pouco comum nas escolas, o selo postal.

As questões ambientais consideradas nesse trabalho representam um tema de grande relevância, pois vêm sendo alvo de preocupação e discussão tanto por parte do meio científico/acadêmico, como também de organizações ambientais e da sociedade como um todo.

Certamente, isso está ocorrendo em decorrência de todas as implicações vinculadas ao âmbito econômico, político, social e ambiental que elas desencadeiam. De forma simultânea, desprendeu-se tempo no desenvolvimento do levantamento realizado para analisar se a filatelia brasileira está cumprindo seu papel de divulgação e incentivo à preservação do meio ambiente no Brasil.

\section{Um breve panorama histórico do início dos selos postais brasileiros}

A necessidade de comunicação do ser humano, assim como de documentar e registrar seus feitos, remonta aos primórdios da nossa história, quando o denominado "homem das cavernas" deixava impresso nas paredes de seu refúgio as imagens dos fatos que mais o impressionavam. Histórias de dinastias inteiras foram gravadas nas paredes dos templos egípcios, enquanto que cartas e recibos comerciais, gravadas em placas de argila, são conhecidos como obras deixadas desde os tempos babilônicos, isto é, cerca de 1850 $\mathrm{AEC}^{4}$.

Deixando de lado a figura mitológica de Mercúrio (associado ao deus grego Hermes), o mensageiro dos deuses, o imperador Ciro da Pérsia (558$528 \mathrm{AEC}$ ), é tido como organizador do primeiro serviço de mensageiros da

\footnotetext{
${ }^{4}$ Abreviação de "antes da Era Comum", notação que vem substituindo o mais usual a.C. (antes de Cristo), visto que atualmente já se sabe que a data do nascimento de Jesus Cristo foi calculada com equívoco pelos primeiros cronologistas. Quando as datas não forem seguidas pelas letras AEC, isso significa que elas pertencem à Era Comum.
} 
Antiguidade, principalmente para divulgar seus feitos de guerra. Porém, 0 primeiro imperador romano Gaius Julius Caesar Octavianus Augustus (63 AEC14) estabeleceu um serviço regular de mensageiros, a pé ou a cavalo, que então se beneficiaram dos excelentes sistemas de estradas já existentes na enorme extensão de territórios do império a partir de Roma. No ano 807, na França, Carlos Magno (747-814), o rei dos francos e imperador do Ocidente, criou os "missi dominici" (mensageiros do senhor) para divulgar suas ordens em regiões mais distantes da monarquia. Desta forma, tentou organizar um "serviço de correios" arrojado, entretanto, o sistema feudal da época dificultava muito o livre trânsito das pessoas encarregadas dessa tarefa.

A partir do século XIII, com a ascensão da burguesia, os serviços de mensageiros, até então uma exclusividade de reis e soberanos, começaram a se difundir entre a classe emergente. Instituições e pessoas influentes recebiam cartas de franquia para explorar serviços diversos. Em 1315, uma escola de Paris, obteve a licença para organizar um serviço de correspondência entre os estudantes e suas famílias. Posteriormente, no século $\mathrm{XV}$, os estados e reinos da Alemanha já eram atendidos por serviços locais de entrega de correspondência, enquanto que os serviços organizados pela família Tasso, na Itália, desde um século antes, expandiam-se para a França, Alemanha, Península Ibérica e região dos Flandres, dominando essa atividade até o final do século XVIII.

No âmbito da História Luso-Brasileira, os correios remontam ao ano 1520, quando Dom Manuel (1469-1521) os instituiu com o nome de "CorreiosMores", e cuja exploração era delegada às famílias ilustres ou mais ligada à Corte. No Brasil, o primeiro correio-mor foi estabelecido em 1663, tendo sido designado para ocupar esse posto o alferes João Cavaleiro Cardoso. Em 1796, seguindo uma tendência observada em toda a Europa de eliminação de privilégios familiares, Dom João VI (1767-1826) extinguiu os "Correios-Mores", passando para o Estado as atribuições dessa instituição.

Até meados do século XIX os serviços prestados pelos correios, como regra geral, eram pagos pelo destinatário por ocasião do recebimento da correspondência. Esse procedimento gerava evidentes problemas e ônus ao erário público, por conta das correspondências devolvidas e endereços não encontrados (SALCEDO, 2010, p.93-94).

$\mathrm{Na}$ Inglaterra, o administrador geral dos correios, Sir Rowland Hill (1795-1879), entendeu que esses serviços deveriam ser pagos antecipadamente. Para tanto idealizou um pequeno retângulo de papel com um valor predeterminado estampado, que seria coletado na missiva ou carta, indicando que ela já estava devidamente franqueada. Nascia assim o selo postal, tendo sido o "Penny Black" o primeiro selo do mundo a entrar em circulação. Isso se deu em 6 de maio de 1840 (SALCEDO, 2010, p.96).

O Brasil aderiu ao uso do selo postal através de dois Decretos $\left(\mathrm{n}^{0} .254\right.$ 
agosto de 1843. Assim, exatamente em $1^{\circ}$ de agosto de $1843^{5}$, os Correios do Império colocaram em circulação os três primeiros selos nacionais com valores de 30, 60 e 90 réis, popularmente denominados "Olhos de boi". Nesse meio tempo o cantão suíço de Zurique já havia emitido uma série de dois valores, para uso local e, dessa forma, o Brasil foi o terceiro país do mundo a efetivamente se utilizar à engenhosa concepção do Sir Hill.

Considerando-se que os selos foram inicialmente concebidos como elementos de franquia, não deve causar surpresa o fato de que as primeiras edições se preocupassem com poucos detalhes além de retratar o valor da taxa a ser paga. Assim, muitos selos pioneiros sequer traziam a identificação do país ou mesmo da moeda a que se referiam. Com o decorrer do tempo e um maior número de selos em circulação, estes passaram gradativamente a exibir desenhos e motivos que caracterizavam o país de origem. Até o final do século XIX as efígies de soberanos, os brasões e as armas dos estados eram os primeiros motivos retratados.

$\mathrm{Na}$ passagem para o século $\mathrm{XX}$, com o surgimento de novas técnicas de gravação, passou-se a dar maior atenção ao valor estético dos selos. Artistas de renome eram chamados para idealizar novas emissões, assim as figuras de deuses e outras alegorias passaram a ser os principais motivos contemplados. A partir de 1920 descobriu-se o valor propagandístico dos selos, sendo que os motivos turísticos, comerciais e patrióticos assumiram posição de destaque no cenário postal. Em 1969, com a criação da "Empresa Brasileira de Correios e Telégrafos" (ECT), artistas plásticos e desenhistas promissores foram contratados para melhorar a qualidade das emissões comemorativas e a Casa da Moeda foi reequipada para garantir uma impressão compatível e de alto padrão.

A qualidade e a criatividade dos selos brasileiros foram e permanecem sendo valorizadas em todo o mundo. Nas últimas décadas vários concursos e exposições nacionais e internacionais envolvendo selos postais comemorativos foram vencidos pela filatelia nacional (CORREIOS, 2003).

\section{Materiais e métodos}

O trabalho envolveu a análise de todos os selos postais emitidos pelo Brasil durante os anos de 1843 a 2013, usando a coleção particular de um dos autores e o auxílio do "Catálogo de Selos do Brasil RHM - 2013" (MEYER, 2013). Por meio desses procedimentos, foi possível perceber que, em concordância ao que ressaltou Diego Andreas Salcedo, "[...] o catálogo RHM é a principal obra de referência filatélica do país, com publicação anual, utilizada pelos colecionadores e comerciantes de selos postais" (SALCEDO, 2010, p.146). Além dessas atuações, fez-se uso da Internet, por meio de consultas a vários endereços eletrônicos acessando o aplicativo "Google", visando cobrir

\footnotetext{
${ }^{5}$ Este data marca o "Dia do Selo Postal" no Brasil.
} 
eventuais lacunas existentes devido à falta de um ou outro material filatélico. $O$ emprego dessas fontes possibilitou reunir todos os selos emitidos pelo Brasil até a atualidade.

Vale ressaltar que durante as consultas realizadas a esses canais, foram contabilizadas 4461 diferentes estampas postais brasileiras, divididas, segundo a proposta de Peter Meyer, nas seguintes categorias: selos regulares, filigranados, comemorativos, Hansen, personalizados, promocionais, blocos e selos-etiqueta (MEYER, 2013). Por não ser significativo, diante das análises a que o trabalho se propôs efetuar, o levantamento não considerou materiais envolvendo: envelopes de primeiro dia de circulação, marcas postais de isenção de porte, folhinhas filatélicas, bilhetes e cartas-bilhete, cadernetas e cartela de selos.

\section{Os temas relacionados ao meio ambiente: resultados alcançados}

Diante do exposto acima, foi possível identificar 258 selos referentes à temática Meio Ambiente, o que representa $5,78 \%$ de todos os selos postais lançados no Brasil no período analisado. Essa significativa quantidade possibilitou revelar a importância do tema aqui tratado. Diante disso, por intermédio de planilhas do Microsoft Excel, todo material foi agrupado, contabilizado e efetuados cálculos estatísticos que serão expostos a seguir. A Figura 1 mostra um histograma de barras comparando as frequências de emissões de todos os selos brasileiros, ano a ano (barra cinza), com as emissões dos selos focando o Meio Ambiente (barra vermelha), segundo levantamento realizado.

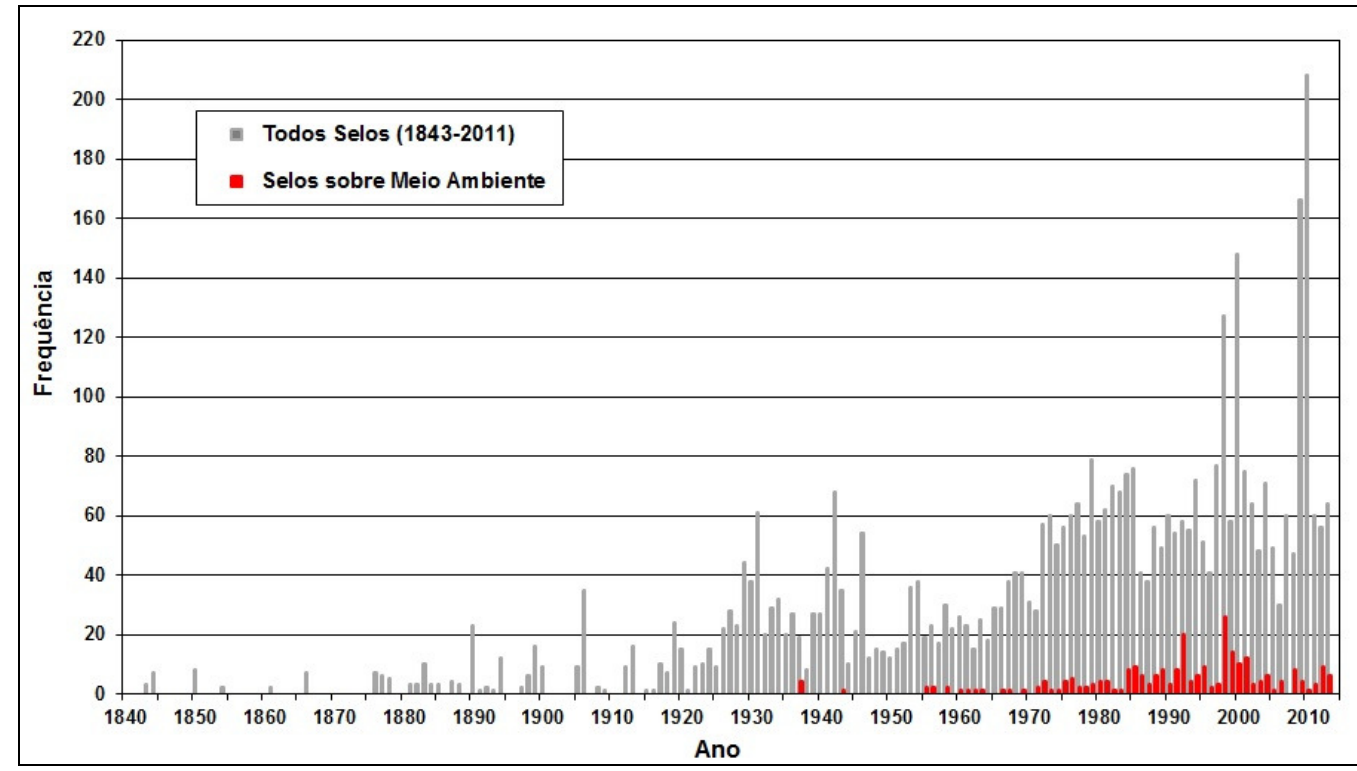

Figura 1: Evolução dos selos postais brasileiros entre 1843 a 2013, comparados com os selos do eixo-temático principal - Meio Ambiente. Fonte: autoria própria. 
Por meio de uma simples análise dessa figura, percebe-se que é possível identificar que os primeiros selos emitidos com o tema Meio Ambiente ocorreram a partir de 1937. De fato, na data de 30/09/1937 foram lançados quatro selos, sendo dois em alusão ao Jardim Botânico no Rio de Janeiro, e os dois restantes em referência às Cataratas do Iguaçu. A figura também revela a modesta evolução na quantidade de emissões desse "eixo-temático principal", destacando a regularidade a partir de 1955, porém com algumas interrupções em 1957, 1959, 1964-65, 1968, 1970 e 2007. Também são notáveis os saltos ocorridos em 1992 (20 selos) e 1998 (26 selos), além dos picos secundários entre essas datas. O primeiro salto deve-se a realização da Conferência das Nações Unidas sobre Meio Ambiente e Desenvolvimento, ocorrida na cidade do Rio de Janeiro (ECO-Rio/92), quando a ECT emitiu estampas em diferentes conotações. Justifica-se o segundo salto em função do bloco contendo 20 selos em alusão à preservação dos "Oceanos: Um Patrimônio para o Futuro", enaltecendo as várias formas de vida marítima.

Diante da miríade de possibilidades vislumbradas pelo eixo-temático principal (Meio Ambiente), decidiu-se dividir em sub-eixos adotando-se uma classificação ambiental alternativa, como revelada na Tabela 1.

Tabela 1: Sub-eixos temáticos associados às áreas ambientais exploradas neste trabalho.

\begin{tabular}{|c|c|c|c|}
\hline Sub-eixo temático & Modalidade & Quantidade & Frequência (\%) \\
\hline \multirow{3}{*}{ Energias } & Renováveis & 10 & 3,87 \\
\hline & \multirow{2}{*}{$\begin{array}{l}\text { Não-renováveis } \\
\text { Economia }\end{array}$} & 4 & 1,55 \\
\hline & & 5 & 1,94 \\
\hline \multirow[b]{2}{*}{ Meio aquático ${ }^{(1)}$} & \multirow{2}{*}{$\begin{array}{l}\text { Preservação } \\
\text { Recursos }\end{array}$} & 36 & 13,96 \\
\hline & & 10 & 3,87 \\
\hline \multirow[b]{2}{*}{ Meio terrestre ${ }^{(2)}$} & \multirow{2}{*}{$\begin{array}{l}\text { Preservação } \\
\text { Recursos }\end{array}$} & 71 & 27,51 \\
\hline & & 5 & 1,94 \\
\hline Meio atmosférico & Preservação & 1 & 0,39 \\
\hline Conotações acadêmicas ${ }^{(3)}$ & Várias & 39 & 15,12 \\
\hline Educação ambiental & Várias & 13 & 5,04 \\
\hline \multirow{3}{*}{ Outros temas $^{(4)}$} & \multirow{3}{*}{$\begin{array}{c}\text { Clima } \\
\text { Reciclagem } \\
\text { Parques nacionais }\end{array}$} & 4 & 1,55 \\
\hline & & 4 & 1,55 \\
\hline & & 56 & 21,71 \\
\hline TOTAL GERAL & & 258 & 100,00 \\
\hline
\end{tabular}

(1) No Meio aquático estão contidos: Oceanos, Rios, Dia Mundial da Água, Recursos Hídricos, etc.

(2) No Meio terrestre estão contidos: Florestas, Cerrado, Dia da Árvore, Mata Atlântica, etc.

(3) As Conotações acadêmicas referem-se a: Institutos, Universidades, Congressos, Agências Financiadoras de Pesquisas, etc.

(4) Outros temas são computados como Clima, Materiais Recicláveis, Parques Nacionais, etc. Fonte: autoria própria. 
Como ainda não existe uma classificação "fechada" para a questão aqui abordada, o Meio Ambiente, optou-se em usar nesta tabela a divisão proposta por Benedito Braga e colaboradores na obra intitulada: "Introdução à Engenharia Ambiental" (BRAGA et al., 2006). Na segunda parte desta obra, os autores propuseram a seguinte divisão para o Meio Ambiente: (1) Energias; (2) Meio aquático; (3) Meio terrestre e (4) Meio atmosférico. Como é possível perceber na referida tabela, decidiu-se adicionar a essa divisão, e consequentemente ao presente trabalho, outros três itens: (5) Conotações acadêmicas; (6) Educação ambiental e (7) Outros temas relacionados à ciência ambiental. Assim, estes sete itens constituem os sub-eixos temáticos tratados nesta pesquisa.

Posteriormente, realizou-se os cálculos estatísticos de selos pertencentes a cada um destes sub-eixos na divisão exposta acima. A Tabela 1 mostra essa estatística destacando a quantidade de selos e a frequência contabilizada em cada sub-eixo e suas modalidades.

Para efeitos de comparações entre as informações aqui analisadas, a Figura 2 mostra um histograma horizontal destacando a distribuição dos selos por cada sub-eixo temático considerado, além da respectiva frequência percentual. Como é possível verificar nessa figura, verifica-se a preferência pelos selos em alusão à preservação do Meio terrestre, com 76 exemplares, dominando $29,45 \%$ de toda amostra avaliada. O sub-eixo denominado Outros temas também se destaca com 64 estampas, ou seja, $21,71 \%$ dos selos trabalhados.

No levantamento realizado, chamou atenção o fato de apenas um selo $(0,39 \%)$ ter sido dedicado ao Meio atmosférico, com a estampa em advertência ao buraco na camada de ozônio existente no planeta.

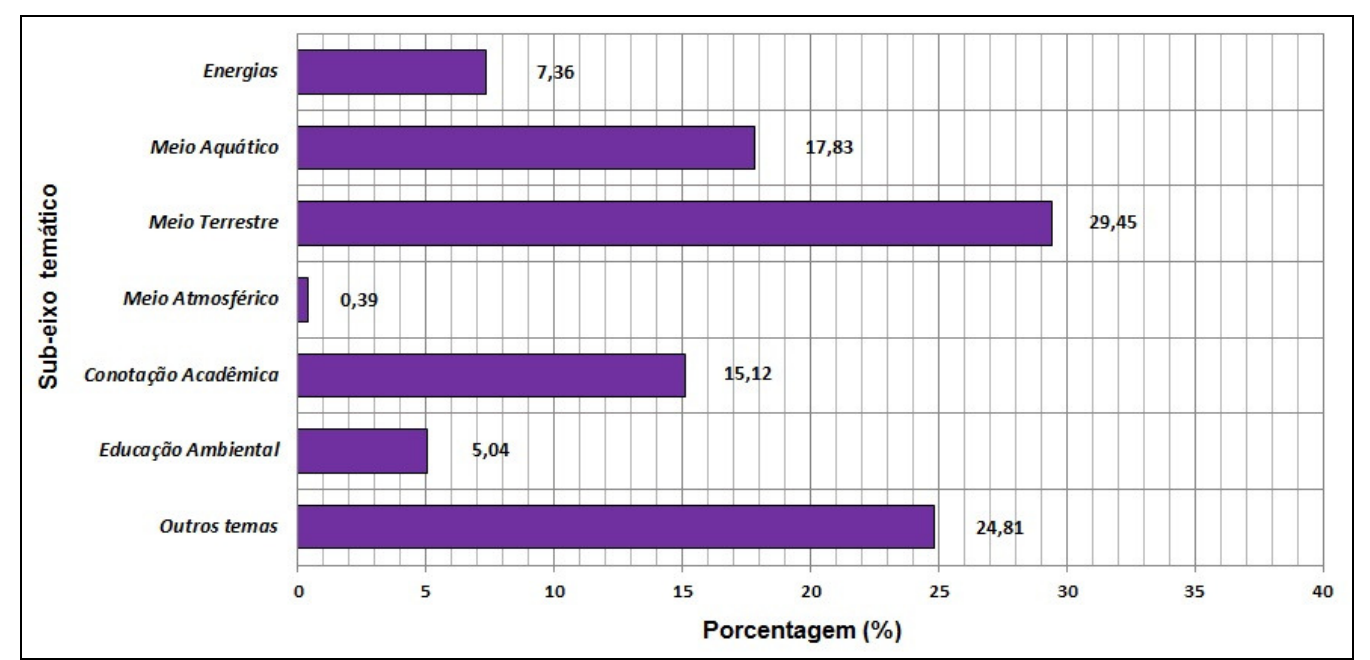

Figura 2: Comparações entre os sub-eixos temáticos diante da frequência de distribuição dos selos postais brasileiros. Fonte: autoria própria. 
Certamente, outros parâmetros poderiam ser melhores avaliados e interpretados a partir das estatísticas apresentadas na Tabela 1 e Figura 2, entretanto, devido ao espaço limitado para esse veículo de comunicação, essas análises não serão aprofundadas neste trabalho, deixando em aberto tais possibilidades.

Nos itens seguintes são apresentados e descritos alguns selos pertencentes a cada um dos sub-eixos temáticos aqui considerados.

\section{Energias}

O trabalho respeitou a classificação tradicional dos recursos energéticos (Energias) ditos primários em renováveis e não-renováveis, feita por Benedito Braga e colaboradores (BRAGA et al., 2006). Porém, adicionouse a essas duas a modalidade denominada economia. Na Figura 3 estão reproduzidos alguns desses materiais filatélicos.

Vale destacar que as fontes renováveis provenientes direta ou indiretamente da energia irradiada pelo Sol podem ser divididas em: (a) energia das marés, como os desníveis criados pelas marés marítimas; (b) energia geotérmica; (c) energia solar; (d) biogás, como o metano, etanol, dentre outros; (e) biocombustível líquido; (f) gás hidrogênio, extraído a partir da decomposição da água doce ou água salgada; (g) hidroeletricidade, obtida por meio da vazão de rios, ou da queda d'água disponível para gerar energia elétrica; (h) energia eólica, empregando turbinas acionadas por vento para gerar energia elétrica e (i) biomassa, como uso de madeira, estrume e carvão vegetal. O levantamento apontou dez selos $(3,87 \%)$ relacionados a essas fontes.

Com relação às fontes não-renováveis, elas podem ser divididas em: (a) combustíveis fósseis (petróleo, xisto betuminoso, etc.); (b) derivados de combustíveis fósseis (carvão); (c) derivados sintéticos; (d) óleos pesados (alcatrão); (e) gás natural (butano e propano); (f) combustíveis nucleares; (g) fusão nuclear (urânio, tório e plutônio) e (h) depósitos geotérmicos confinados (vapores). Do total de selos na temática Meio Ambiente, quatro estampas $(1,55 \%)$ foram selecionadas como pertencentes à energia do tipo nãorenováveis e cinco $(1,94 \%)$ pertencentes à economia de energia.

As usinas hidroelétricas são as fontes de recursos energéticos renováveis mais utilizados pelo Brasil, pois, segundo Anuário 2010 - Análise Energia, em 2008 elas constituíam quase 73,2\% de toda energia elétrica gerada no território nacional $\left(361 \mathrm{TWh}^{6}\right)$, cabendo ao país o terceiro lugar mundial entre os maiores geradores dessa modalidade de energia, ficando atrás da China (522 TWh) e do Canadá (369 TWh) (ANUÁRIO, 2010). As Figuras 3.1 e 3.2 reproduzem os selos emitidos em homenagens às inaugurações da Usina Hidroelétrica de Paulo Afonso, no rio São Francisco,

\footnotetext{
${ }^{6}$ TWh indica a unidade Tera Watt-hora de energia, isto é, 1.000.000.000.000 Watts hora.
} 
divisa da Bahia e Alagoas, e da Usina Hidroelétrica de Jupiá, no rio Paraná, divisa de São Paulo e Mato Grosso do Sul.

Tendo em vista a preservação de recursos energéticos, praticamente no auge da "Crise Mundial do Petróleo", a ECT lançou em 1976 dois selos alertando os consumidores para a economia de eletricidade e de combustíveis. A Figura 3.3 mostra um dos selos dessa campanha, destacando um veículo e, abaixo deste, os dizeres: "sabendo usar não vai faltar".

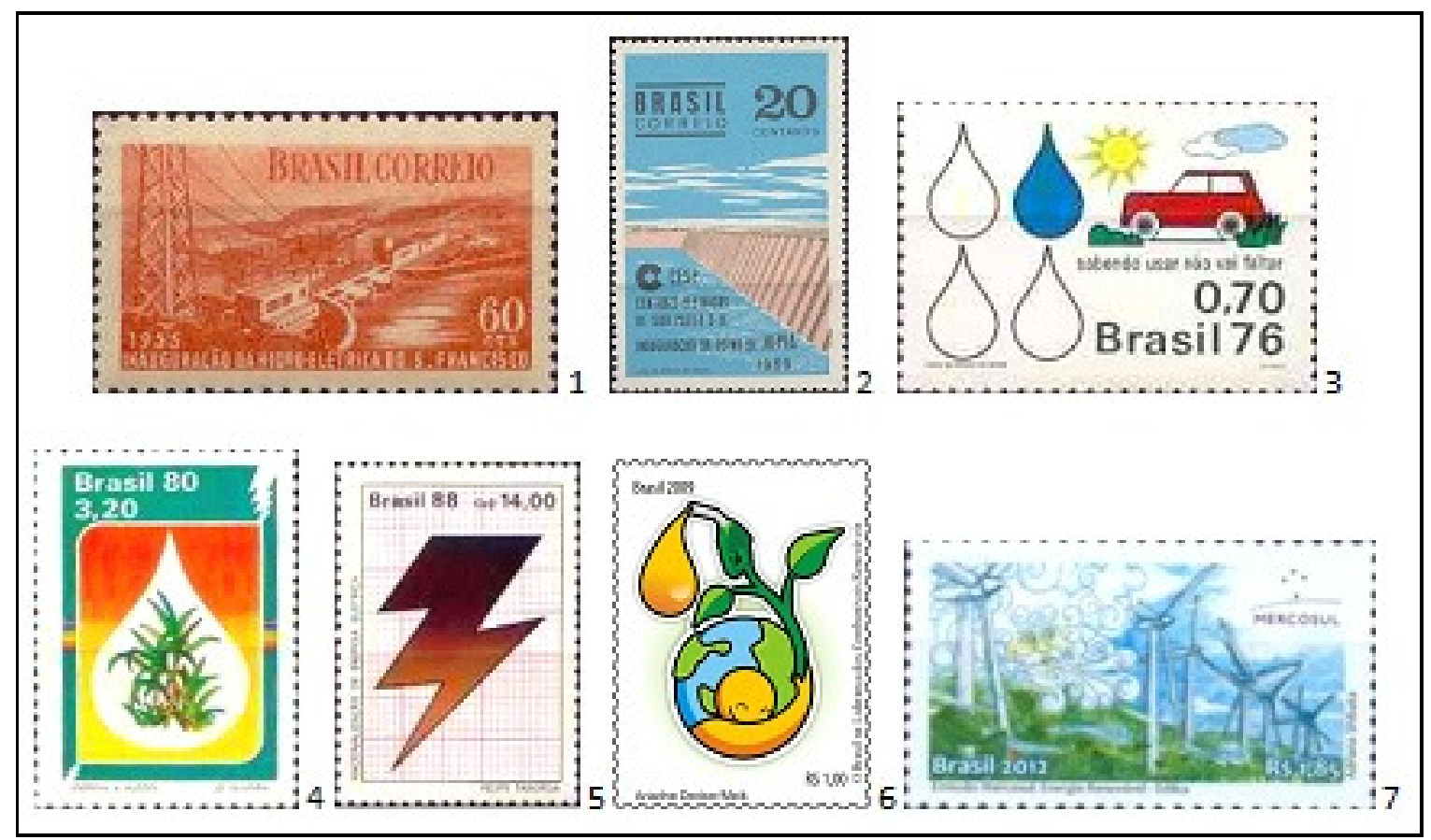

Figura 3: Seleção de alguns selos do sub-eixo temático Energias, lançados pela ECT. Fonte: Empresa Brasileira de Correios e Telégrafos (ECT, 2013).

As "Alternativas Energéticas", dentre elas o álcool, a solar, a eólica e a hidro, compõem os quatro selos lançados em 02/01/1980 pela ECT. O selo reproduzido na Figura 3.4 mostra a cana de açúcar no interior de uma gota em referência à produção do etanol, o qual o Brasil é líder mundial desse combustível, enquanto que a estampa da Figura 3.7, lançada em 09/12/2012 em homenagem ao MERCOSUL, revela uma imagem de um parque eólico.

A "Racionalização de Energia", tanto para a economia de petróleo como para a eletricidade, foram temas de dois selos emitidos em 1988. As Figuras 3.5 e 3.6 mostram, respectivamente, um raio que lembra uma descarga elétrica e uma gota de petróleo, ambas em alusão à necessidade de se realizar a economia de energia elétrica e combustível.

O Brasil na liderança dos combustíveis renováveis foi o tema do selo 
segurando um pé de cana de açúcar, onde na ponta está estilizada uma gota saindo de uma bomba de combustível.

\section{Meio aquático}

A água é um dos recursos naturais mais intensamente utilizados, sendo fundamental para a existência e a manutenção da vida. Dentre os diferentes usos da água, podem-se destacar aqueles relacionados ao abastecimento humano, abastecimento industrial, irrigação, geração de energia elétrica, navegação, transporte de poluentes, preservação da fauna e flora, aquicultura, recreação, dentre outros.

Para compor o sub-eixo denominado Meio aquático foram identificados $46(17,83 \%)$ selos do total da amostra avaliada. Na Figura 4, os quatro primeiros selos são referentes a esse tema, destacando os em alusão à preservação e aos recursos, e que foram julgados como os mais significativos, tanto pela mensagem ilustrada como pela relevância do tema exposto.

A Figura 4.1 mostra a estampilha impressa em apenas duas cores que reproduz o logotipo relativo ao "Decênio Hidrológico Internacional" (1965-1974), patrocinado pela UNESCO, com a colaboração de outras entidades da Organização das Nações Unidas. O "Dia Mundial da Água", comemorado em 22 de março de cada ano, foi o tema dos selos lançados em 1997 e 2004, reproduzidos nas Figuras 4.2 e 4.3, respectivamente. Na primeira estampa 0 globo terrestre aparece mergulhado num copo contendo água, enquanto que na segunda, uma pessoa suporta uma gota d'água. Ambas as estampas são em alusão à procura intensa da humanidade pela necessidade de água potável, cada vez mais escassa no planeta. O Ano Internacional de Cooperação pela Água foi o assunto retratado nos dois selos emitidos em 08/03/2013, ambos mostrados nas Figuras 4.4 e 4.5 .

No bloco filatélico de 2002, reproduzido na Figura 4.6, há uma referência à preservação ambiental, enfocando no mapa da costa sul brasileira, mais especificamente na região entre Florianópolis (SC) e Rincão (RS), como uma "Área de Proteção Ambiental da Baleia Franca" (MEYER, 2013, p.253), considerada como a segunda espécie de baleia mais ameaçada de extinção do planeta (BALEIA FRANCA, 2013). 


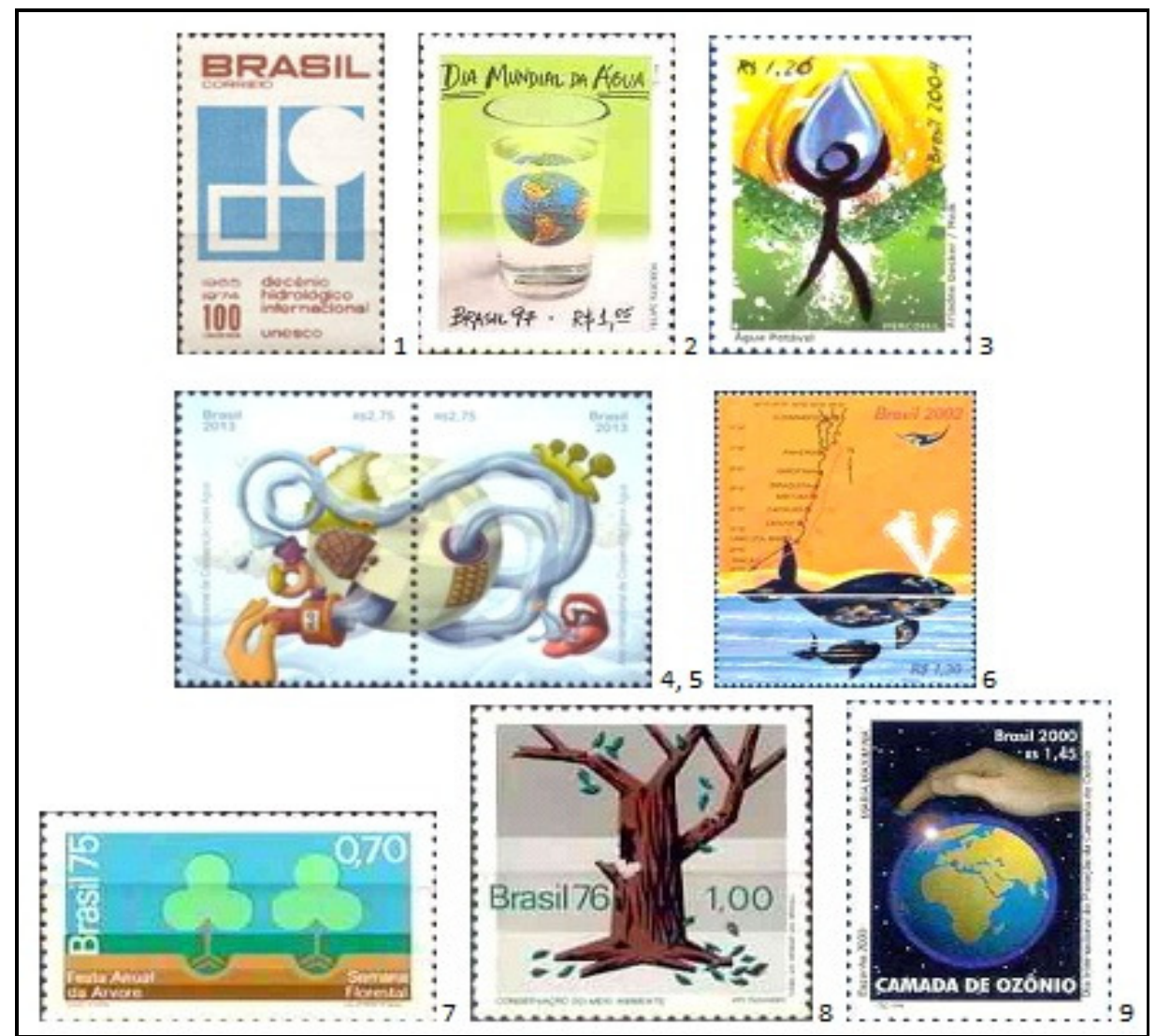

Figura 4: Alguns selos selecionados que compõem os sub-eixos temáticos Meio aquático, Meio terrestre e Meio atmosférico, lançados pela ECT de alguns selos do sub-eixo temático Energias, lançados pela ECT. Fonte: Empresa Brasileira de Correios e Telégrafos (ECT, 2013).

\section{Meio terrestre}

O uso do solo se intensifica na medida em que a expansão do crescimento populacional ocorre, visto que ele vem sendo ocupado e cultivado para extrair o sustento do homem, para seus deslocamentos e para a flora e fauna. Do ponto de vista ambiental, pode-se dizer que as preocupações com o uso e manejo do solo estão associadas aos fenômenos de erosão, emprego excessivo de fertilizantes e defensivos agrícolas (inseticidas, fungicidas e herbicidas), irrigação e salinização, além dos resíduos sólidos urbanos, industriais e radioativos.

O Meio terrestre é o sub-eixo que possui o maior número de selos postais realizados neste levantamento. Foram identificados 76 (29,45\%) estampas que compõem esse sub-eixo temático. Neste sentido, destaca-se a "Festa Anual da Árvore" e a "Semana Florestal" compõe o tema do selo reproduzido na Figura 4.7. Enquanto que a "Conservação do Meio Ambiente" foi o foco do selo de 1976 (Figura 4.8) que ilustra uma árvore desfigurada se desfolhando. 


\section{Meio atmosférico}

$\mathrm{Na}$ atmosfera terrestre, do ponto de vista ambiental, destacam-se duas camadas principais: a troposfera e a estratosfera. Na troposfera, desenvolvemse todos os processos climáticos que regem a vida no planeta. Não obstante, é nessa região que ocorre os diversos fenômenos relacionados à poluição do ar. $\mathrm{Na}$ estratosfera, ocorrem as reações importantes para o desenvolvimento das espécies vivas, em razão da presença da camada de ozônio.

Neste sentido, podem ser destacados os seguintes poluentes atmosféricos: dióxido de carbono $\left(\mathrm{CO}_{2}\right)$; óxidos de enxofre $\left(\mathrm{SO}_{2}\right.$ e $\left.\mathrm{SO}_{3}\right)$; óxidos de nitrogênio $\left(\mathrm{NO}_{\mathrm{x}}\right)$; hidrocarbonetos; oxidantes fotoquímicos; material particulado; asbestos (amianto); metais; gás fluorídrico (HF); amônia $\left(\mathrm{NH}_{3}\right)$; gás sulfídrico $\left(\mathrm{H}_{2} \mathrm{~S}\right)$; pesticidas e herbicidas; substâncias radioativas, as ilhas de calor excessivo, os excessos de ruído (poluição sonora) e de luz (poluição luminosa), essas três últimas manifestadas mais notoriamente nos grandes centros urbanos.

No que concerne aos principais problemas globais de poluição do ar, pode-se enfatizar o efeito estufa, a destruição da camada de ozônio e as chuvas ácidas.

Como comentado anteriormente, o presente estudo revelou apenas um selo $(0,39 \%)$ pertencente a esse sub-eixo temático. A Figura 4.9 mostra a estampa emitida em 16/09/2000, destacando uma mão sobre o planeta Terra em referência à necessidade de maiores cuidados e proteção com o mundo, devido ao aumento do buraco na camada de ozônio existente na atmosfera.

\section{Conotações acadêmicas}

O levantamento realizado identificou 39 selos postais, ou seja, 15,12\% do total da amostra, que retratam as denominadas Conotações acadêmicas, isto é, eventos científicos nacionais e internacionais, além de Instituições de ensino e pesquisas voltadas para o Meio Ambiente.

Como comentado anteriormente, o ano de 1992 foi marcante para as Ciências do Meio Ambiente devido, principalmente, a ECO-Rio/92. Em função deste evento, a ECT emitiu 21 selos com conotações diferentes envolvendo flora, fauna, expedições, preservação, dentre outras. Na Figura 5.1 está reproduzida uma das quatro estampas com a denominada "Turma da Mônica Ecologia", em comemoração a este evento, onde aparece o personagem Cebolinha navegando num barco a remo, com borboletas, pássaros e flores ao seu redor, em alusão a importância de preservar a natureza. O selo reproduzido na Figura 5.2, também em referência à ECO-Rio/92, mostra o globo terrestre e, em destaque, o mapa do Brasil, estando sobreposto um pássaro e uma flor, enfatizando a fauna e a flora.

O "Programa Nacional de Gerenciamento Costeiro" (GERCO) foi o tema do selo emitido em 16/05/2000 (Figura 5.3). Este material filatélico foi elaborado levando-se em consideração algumas espécies que vivem no litoral 
atlântico, como as tartarugas (em destaque), os caranguejos, os pássaros, os coqueiros, os manguezais, dentre outros. A figura também ilustra o mapa do Brasil, em ponto menor, com uma faixa em vermelho e os dizeres " $8.698 \mathrm{~km}$ de Zona Costeira".

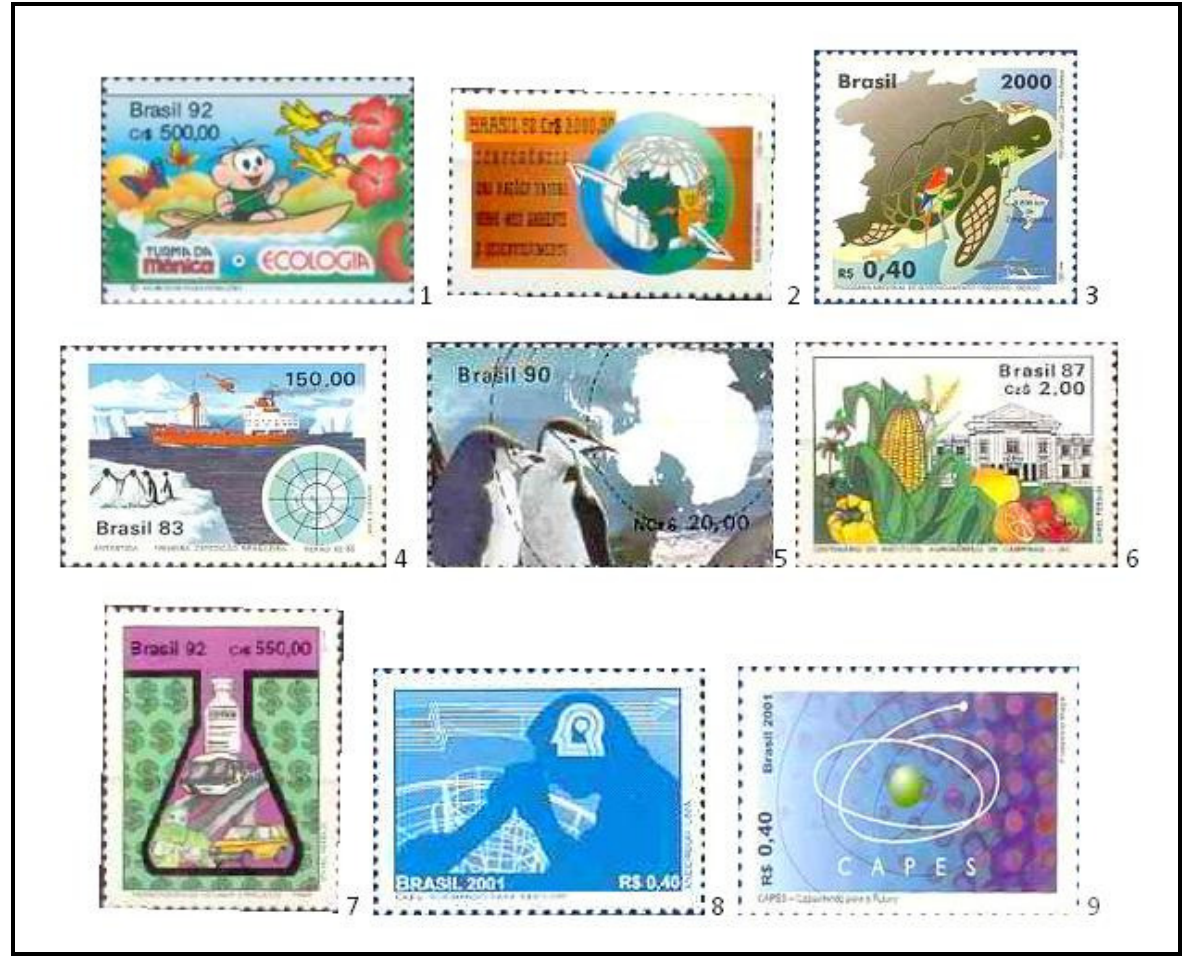

Figura 5: Uma pequena amostra de selos que mostram Conotações acadêmicas, como: congressos e encontros científicos, instituições de ensino e pesquisas, além de agências financiadoras de estudos e pesquisas. Fonte: Empresa Brasileira de Correios e Telégrafos (ECT, 2013).

O Brasil confirmou a presença e ocupação no continente antártico por meio da primeira expedição realizada no verão 82/83. O selo postal reproduzido na Figura 5.4 remete a lembrança deste evento, onde aparece um céu azul, mar calmo, icebergs, quatro pinguins, além do navio pesquisa "Barão de Tefé" em movimento, helicóptero voando, a bandeira brasileira no mastro e o mapa azimutal do continente austral. O "Programa Antártico Brasileiro" (PROANTAR) e a fauna antártica foram os assuntos do selo emitido em 22/02/1990 (Figura 5.5), destacando-se dois pinguins e o mapa da Antártica.

Algumas escolas e/ou centros de pesquisas que ministram cursos e realizam pesquisas voltadas ao Meio Ambiente foram computados no levantamento filatélico aqui analisado. O selo emitido em 27/06/1987, reproduzido na Figura 5.6, foi em homenagem ao centenário do Instituto Agronômico de Campinas (IAC), centro de excelência no ensino e pesquisas voltadas à agronomia, agricultura, meteorologia e ações voltadas ao Meio Ambiente. 
O selo da Figura 5.7 foi emitido com a intenção de homenagear uma das agências de financiamento de pesquisas no Brasil: Financiadora de Estudos e Projetos (FINEP). A figura central estampada no selo possui um balão de Erlenmeyer, preenchido por elementos daquilo que é partícipe e produto de algumas atividades das pesquisas nacionais. O frasco branco remete ao uso de substâncias químicas ou aos fármacos; um trem de design arrojado e sobre trilhos elevados, o que remete à inovação tecnológica; um automóvel, outro produto tecnológico que constantemente sofre inovações e, por fim, a figura de uma pessoa segurando equipamentos científicos para análises. Observa-se ainda que tudo isso foi demarcado sob um fundo lilás, sendo que um processo de destilação da inovação nacional depende de financiamento, daí a parte externa ao balão preenchida por cifrões.

Sendo importantes órgãos de pesquisas, inclusive patrocinando trabalhos científicos voltados para questões ambientais, a ECT destacou o Conselho Nacional de Desenvolvimento Científico e Tecnológico (CNPq) e a Coordenação de Aperfeiçoamento de Pessoal de Nível Superior (CAPES) nas emissões de 17/04/2001 e 11/07/2011, respectivamente. O CNPq foi lembrado na estampa reproduzida na Figura 5.8, que evidencia uma pessoa observando por meio de um microscópio e, tendo em sua cabeça, o logotipo desta agência de financiamento de pesquisas. Ainda neste contexto, a CAPES foi homenageada com um selo que está reproduzido na Figura 5.9. Esta última figura evidencia no primeiro plano o logotipo da entidade, além dos dizeres: "Capacitando para o Futuro", em alusão a uma das ações promovidas por esta agência financiadora de pesquisas.

\section{Educação ambiental}

A Educação Ambiental é um processo participativo, onde o educando assume o papel de elemento central do processo de ensino e aprendizagem pretendido, atuando ativamente no diagnóstico dos problemas ambientais e buscando soluções para os mesmos. Sendo um agente transformador, por meio do desenvolvimento de habilidades e formação de atitudes, utiliza conduta ética, condizentes ao exercício da cidadania. Dado o extenso material filatélico presente neste trabalho, a rigor, seu riquíssimo conteúdo se encaixa neste sub-eixo temático em discussão, tendo sido denominado de Educação ambiental.

O primeiro dos 13 selos (5,04\%) brasileiros em alusão a temática Educação ambiental, identificado no levantamento filatélico aqui tratado, está reproduzido na Figura 6.1. Esta peça, emitida em 30/09/1956, foi elaborada em uma única cor (o monocromático em tom verde). A figura mostra, em meio ao ambiente florestal, o mapa do Brasil com uma árvore ao seu centro e, estando ao lado esquerdo, as cinco principais estrelas que compõe a constelação do Cruzeiro do Sul, todos envolvidos pelo tema em evidência que era a "Campanha de Educação Florestal" de 1956. 
A "Campanha da Proteção Nacional" de 1973 foi celebrada pela emissão de quatro selos destacando a natureza, a cultura, o vôo e contra os incêndios. A Figura 6.2 mostra o selo relativo à "Campanha da Natureza", estilizando uma mão suportando uma folha. A figura parece deixar no ar um sutil recado: "a natureza também está nas mãos do Homem".

Em 1981 a ECT lançou uma quadra em alusão à "Proteção ao Meio Ambiente". Os selos reproduzidos nas Figuras 6.3, 6.4, 6.5 e 6.6 mostram detalhes dos elementos, água, floresta, ar e solo, respectivamente. Da mesma maneira, um coração em amarelo sobreposto a uma folha e ao mapa do Brasil, com os dizeres "VERDE TE QUERO VERDE", são os elementos visuais encontrados na estampa reproduzida na Figura 6.7 alusiva ao "Programa Nossa Natureza", de 1989. Todos estes selos difundem elementos discursivos do campo científico para um público heterogêneo, nacional e internacional.

Por fim, o desenvolvimento sustentável foi tema da Série Geologia emitida em 19/05/2000 pela ECT. Os três selos reproduzidos nas Figuras 6.8, 6.9 e 6.10 destacam o $31^{\circ}$ Congresso Geológico Internacional ocorrido na cidade de Hannover, na Alemanha; tendo como tema as Geociências e os Metais Brasileiros, respectivamente. A série ainda destaca a imagem do mapa do Brasil, com as localizações das principais reservas de minérios, além de figuras que compõem algumas pedras preciosas.

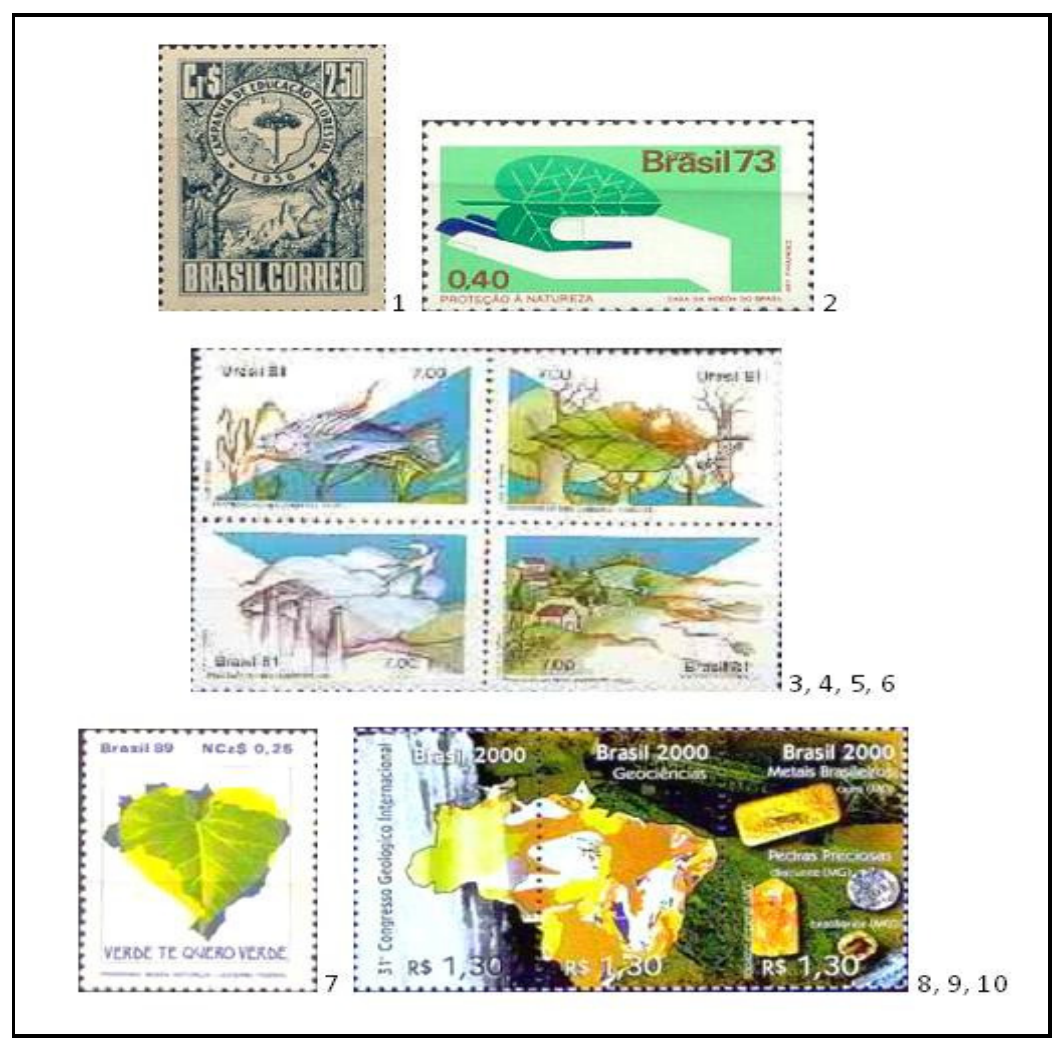

Figura 6: Selos que retratam o sub-eixo temático Educação ambiental enfatizando as campanhas de proteção, preservação e sustentabilidade ambiental. Fonte: Empresa Brasileira de Correios e Telégrafos (ECT, 2013).

Revbea, São Paulo, V. 10, № 1: 97-117, 2015. 


\section{Outros temas}

Ao analisar o histograma da Figura 2 verifica-se que o sub-eixo denominado Outros temas possui um expressivo número de selos. Foram 64 estampas $(24,81 \%)$ identificadas no levantamento, que estão relacionadas ao clima, aos materiais recicláveis, aos parques e aos recursos nacionais.

O "Dia Meteorológico Mundial", comemorado a cada 23 de março, foi o tema do selo emitido em 1962. Neste material monocromático em tom marrom, reproduzido na Figura 7.1, mescla a ilustração do Sol, nuvens e chuva, além de alguns sinais específicos desta ciência. No entanto, de maneira bem diferente, o selo emitido em 1967, reproduzido na Figura 7.2, em alusão a mesma data, mostra parte do planeta e da atmosfera terrestre, além de um foguete se deslocando. Possui ainda as siglas da agência especializada das Nações Unidas para o clima, a "OMM" - "WMO", isto é, a Organização Meteorológica Mundial e Word Meteorological Organization, respectivamente.

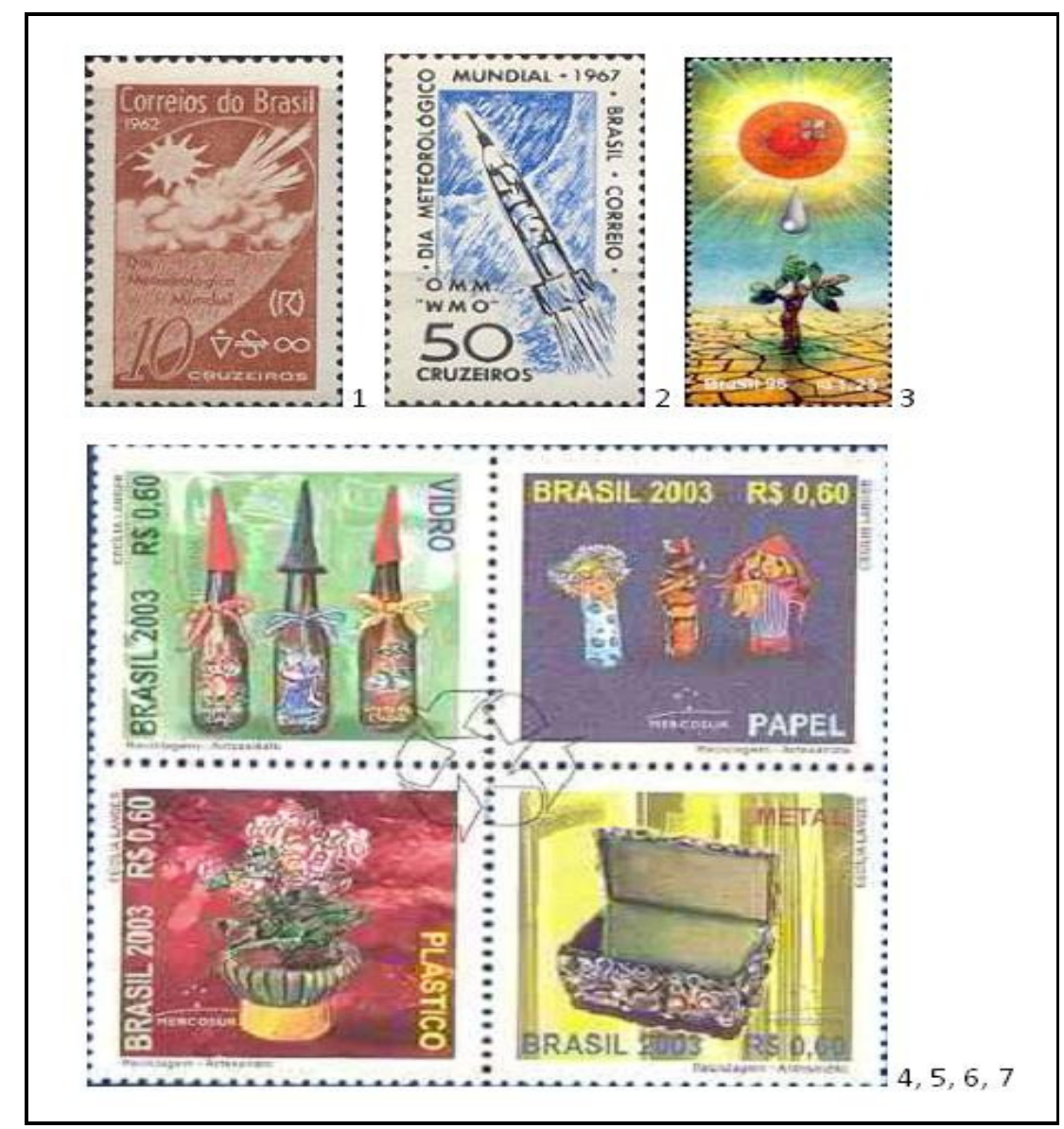

Figura 7: Alguns selos que compõem o sub-eixo temático Outros temas retratando assuntos relacionados ao clima, materiais recicláveis, parques nacionais, dentre outros. Fonte: Empresa Brasileira de Correios e Telégrafos (ECT, 2013). 
O "Dia Mundial de Luta Contra a Desertificação" foi o tema da estampa emitida em 17/06/1996, que está reproduzido na Figura 7.3. Nele vê-se um sol escaldante incidindo sobre uma pequena árvore florescendo num solo árido e rachado, mas que sobre ela cai uma gota d'água, procurando, desta maneira, transmitir um sinal de esperança para as regiões brasileiras sofridas com as secas.

O bloco, cujo tema foi a "Reciclagem em Artesanato", composto por quatro selos reproduzidos nas Figuras 7.4, 7.5, 7.6 e 7.7, mostram, respectivamente, vidro (em três garrafas estilizadas, com laços coloridos, chapéus e rótulos com dançarinos), papel (em três bonecos estilizados), plástico (com as flores num vaso) e metal (um baú decorado, mas aberto). Vale destacar que em cada um destes selos aparece o logotipo do Mercosur, e não MERCOSUL (que seria o correto), com as cinco estrelas da constelação do Cruzeiro do Sul.

Como se pode constatar na pequena, porém significativa, amostra ilustrada neste trabalho, os selos postais comemorativos detêm na sua minúscula figura uma variedade de signos que, muitas vezes deixam de ser signos, passando a ser encarados como veículos de transmissão de verdades estabelecidas, de significações de mundo e de sentidos socialmente construídos (SALCEDO, 2010).

\section{Possíveis implicações do uso dos selos postais no ensino}

Constata-se que o conceito de Educação Ambiental é por demais complexo, abstrato e dificilmente partilhado. Atualmente pode-se afirmar que 0 estudo do Meio Ambiente, por meio de uma Educação Ambiental, é um importante canal para o indivíduo ser estimulado e exercitar plenamente a sua cidadania. Em particular, neste tocante, muito se deve ao relevante papel da mídia brasileira nas últimas duas décadas. No entender de Manuel Castells, foi justamente por meio da ampla divulgação da questão ambiental na mídia que o tema ganhou mais espaço no âmbito das sociedades contemporâneas. Além disso, o autor avalia que o movimento ambiental demonstrou grande capacidade de divulgação, criando elementos propícios para matérias e reportagens. Com isso, os ideais de preservação proliferaram com auxílio da mídia, que reproduz ou refuta as ideologias de alguns movimentos sociais (CASTELLS, 2000).

No entanto, de acordo com Enrique Leff, a crise ambiental problematiza os paradigmas estabelecidos do conhecimento e demanda novas metodologias capazes de orientar um processo de reconstrução do saber, que permita realizar uma análise integrada da realidade. A problemática ambiental que integra processos naturais e sociais não pode ser compreendida sem a interferência de diversas áreas do saber. Segundo esse autor, a questão ambiental é uma problemática de caráter eminentemente social e cultural, e isto precisa ser agregado na divulgação ambiental (LEFF, 2002, p.134). 
Foi justamente pensando nesta interdisciplinaridade e na necessidade da criação de novos mecanismos que convertam conhecimentos e avaliações sobre as questões ambientais, que se sugere o uso dos selos postais nos trabalhos desencadeados por professores em suas atividades acadêmicas.

É importante lembrar que para um colecionador e até mesmo para um estudante, uma simples paisagem exibindo uma queda d'água, uma árvore desfolhada, o planeta visto do espaço, uma praia, ou uma baleia estilizada, pode ser explorada de algum ponto de vista num trabalho relacionado ao Meio Ambiente. Entretanto, é necessário tomar os devidos cuidados ao diferenciar os selos nos quais o motivo temático apenas faz parte da "paisagem de fundo" daqueles em que esse tema é o principal motivo estampado. Justamente, nesse último grupo são encontrados alguns dos mais belos e úteis selos de divulgação para o uso por professores e seus estudantes em atividades acadêmicas. Neste contexto, os selos postais podem servir como mais uma opção para o ensino e para a aprendizagem, pois esse material é um recurso atraente, podendo fazer uso de dispositivos auxiliares como retroprojetores, datashow, fotografias, Internet, dentre outros.

Com certeza, a abordagem educativa ainda é um desafio para muitos educadores, indicando que há um longo caminho a ser percorrido. Vale, porém, ressaltar que a aprendizagem em questões ambientais, além de outros conteúdos científicos a elas relacionados, pode acontecer em âmbitos diversificados, como no caso da educação formal, informal ou, ainda, nas atividades destinadas à popularização da Ciência. Assim, quanto mais ampla a divulgação, a disseminação e a difusão dos conteúdos existentes nos selos postais, mais facilmente e com maior eficiência ocorrerá à transposição didática de saberes científicos.

Desde que tais espaços não formais, como os que foram aqui propostos, sejam utilizados com a finalidade de participar dos processos de ensino e aprendizagem de forma planejada, sistemática e articulada, o material filatélico empregado deixa de ser uma mera atividade educacional de complementação ou de lazer. Na verdade, ele passa a se tornar uma contribuição para a educação e o aprendizado de conteúdo geral ou, em certas aplicações, específicas de disciplinas com conteúdos associados ao Meio Ambiente.

No caso de atividades envolvendo as questões ambientais por meio dos selos postais, o diagrama da Figura 8 apresenta uma sugestão para uma abordagem didática. Este diagrama tem como objetivo mostrar que tanto os professores e os estudantes podem utilizar a problemática ambiental retratada por meio de selos postais. Os aspectos visuais contidos nas estampas postais podem despertar a curiosidade e o interesse das pessoas e, como consequência, resultar na aquisição de novos conhecimentos em outras áreas do conhecimento. Especificamente em relação às questões ambientais, os aspectos visuais contidos nos selos postais possibilitam desenvolver temas culturais, econômicos, políticos, históricos, biológicos, geográficos, ecológicos e sociais, reforçando o desenvolvimento da questão ambiental abordada. Tais

revista brasileira educação ambiental 
componentes favorecem um aprendizado significativo e motivador, auxiliando na formação de um cidadão crítico.

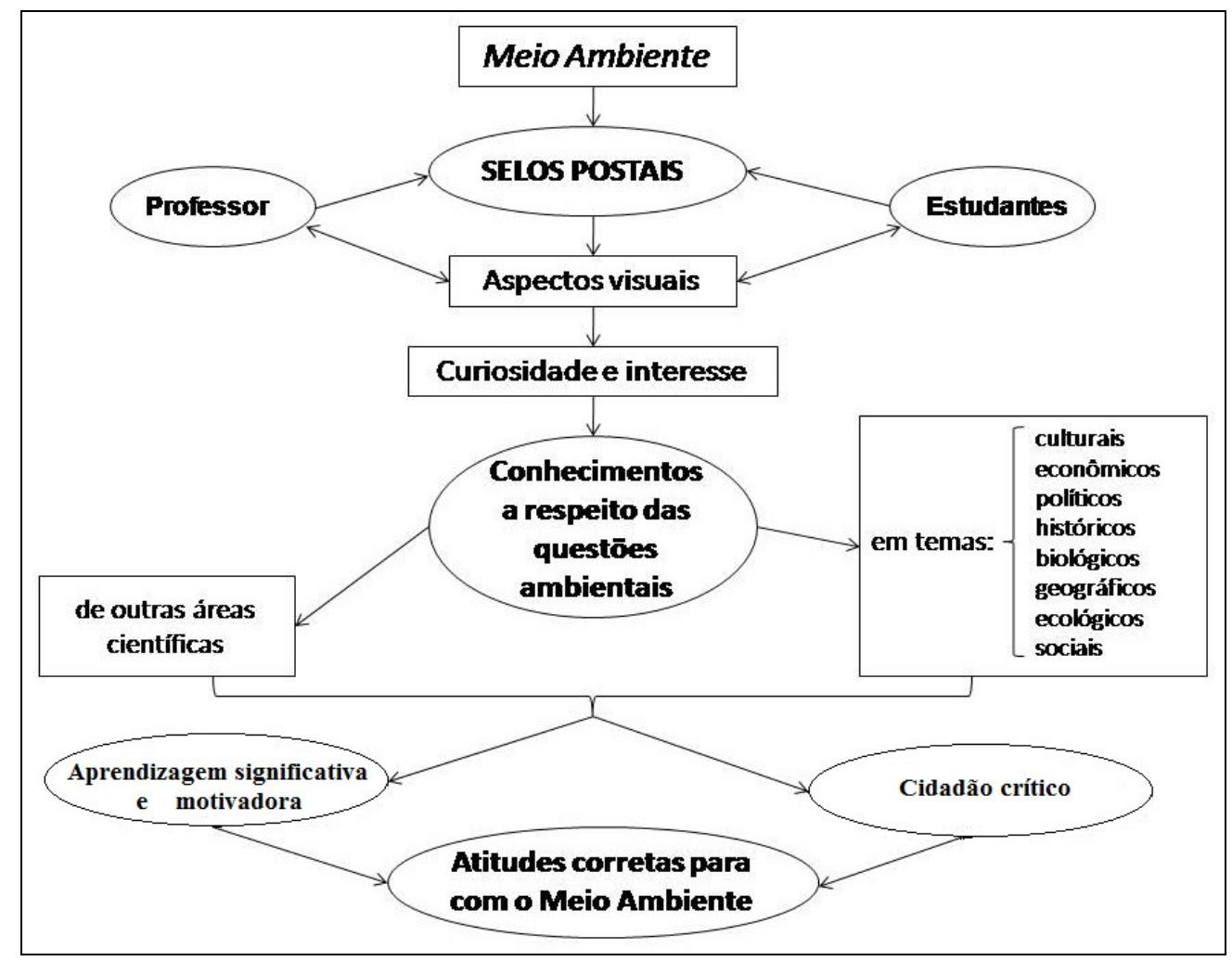

Figura 8: Diagrama básico de uma abordagem didática com o uso de selos postais nas questões envolvendo Meio Ambiente. Fonte: autoria própria.

O presente trabalho defende a possibilidade de desenvolver as questões ambientais empregando os selos postais. Esse tipo de material pode ser usado na abordagem dessas questões quando o professor as exploram em sala de aula. Cabe a ele, por meio de algumas tarefas, possibilitar que o estudante não apenas fixe o conteúdo estampado nas figuras dos selos, mas também aquilo que está por trás de cada imagem e dos momentos associados à elaboração do tema ambiental estudado e da relevância de suas implicações nas atividades humanas do dia-a-dia.

Neste sentido, o professor pode elaborar diferentes questões com o auxílio das estampas postais, por exemplo, relacionando o conteúdo das imagens com as realizações ou descobertas científicas, com o momento histórico, com as interseções entre as várias ciências e com as consequências para a humanidade.

Assim, diante das questões ambientais, refletir sobre a problemática é condição essencial para formar um "professor educador ambiental". Pois, segundo as análises feitas por José Contreras, "a partir do momento em que o 
profissional assume o papel no processo, ele passa a fazer parte dessa situação se inserido em um contexto mais amplo que é o contexto social" (CONTRERAS, 2000).

Diante da atual crise socioambiental que é do conhecimento de muitos, - professor precisa ultrapassar a racionalidade que prioriza os saberes científicos e tecnológicos. Ele deve também buscar o desenvolvimento de um planejamento pedagógico que contemple a relação entre ser humano e meio ambiente, capaz de acompanhar as mudanças sociais e ambientais da sociedade em que vive. Desta maneira, o trabalho por ele desenvolvido também será mais abrangente, instigante e gratificante, deixando seus estudantes motivados, mais participativos nas atividades desenvolvidas e agregando novos conhecimentos.

\section{Considerações finais}

Talvez, por falta de tempo no dia-a-dia ou por ser o selo um pequeno e insignificante fragmento de papel descartável que apenas indica a taxa cobrada pelo envio de uma correspondência, as pessoas acabam por desprezar o devido valor desse material. Entretanto, na atualidade mais do que nunca, esse pequeno pedaço de papel nem chega a ser percebido como um documento, propriamente dito. Ocorre que o selo postal é muito mais que isso, pois muitas estampilhas são impressas com motivos que envolvem aspectos econômicos, políticos, culturais, científicos, dentre outros. Nesse sentido, os trabalhos de Castro, Diniz e Barros (2007); Salcedo e Gomes (2009) e Salcedo (2010), fazem um bom retrospecto do desenvolvimento e da importância do material filatélico brasileiro.

Como comentado anteriormente, o trabalho aqui apresentado, além de revelar uma miríade de possibilidades de estudo dos conteúdos dos selos postais brasileiros, também mostra a cientificidade ilustrada nesses artefatos. Certamente, este material pode ser trabalhado nos vários níveis escolares, em particular em disciplinas que possuam interfaces com o Meio Ambiente. Além disso, pode ser oportuno ampliar essa visão e estudar, as possíveis representações e usos sociais do selo postal, por meio da apropriação de novos discursos ou reformulações dos mesmos, para verificar a difusão das questões ambientais que esse artefato carrega.

Um resultado esperado desse trabalho está relacionado com o fato de que se desenvolvam algumas condições para que tanto os professores como os pesquisadores, além de estudantes e o público em geral, tenham a possibilidade de olhar atentamente para o selo postal como um instrumento didático e científico que difunde as diferentes manifestações culturais de uma sociedade. Propõe-se que, a partir de estratégias discurso-textuais específicas esse tipo de material possa ser considerado como objeto que registra o fato, a memória, impedindo o acontecimento do esquecimento. Também se propõe a utilização do selo postal como instrumento pedagógico, como uma ferramenta 
de fácil manuseio, baixo custo, que provoca o processo criativo e auxilia na leitura das realidades envolvidas nos diferentes temas ambientais.

A composição e harmonia entre os diferentes símbolos impressos em vários selos postais pertencentes a esse levantamento, seguindo os critérios estabelecidos neste trabalho, possibilitam afirmar que o material filatélico difunde elementos que caracterizam um domínio discursivo científico ou uma cientificidade. Nesse sentido, os selos postais podem ser empregados como um veículo disseminador da Ciência, além de servir como ferramenta adicional para o professor atuar com seus estudantes em trabalhos dentro e fora da sala de aula.

Pode-se afirmar que o trabalho envolvendo o levantamento filatélico aqui exposto permitiu descobrir nuances a respeito do discurso científico, além de inferir algumas relações subjacentes ao seu regime de informação.

\section{Agradecimentos}

Ao Conselho Nacional de Desenvolvimento Científico e Tecnológico (CNPq/Processo 13.127/2012-13) que concedeu a Monica Cristina Meschiatti a bolsa de Iniciação Científica para o desenvolvimento parcial deste trabalho.

\section{Referências}

ANUÁRIO. Geração Elétrica. Anuário 2010 - Análise Energia. São Paulo: Impressão Gráfica Prol, pp. 72-79, 2010.

BALEIA FRANCA. Projeto Baleia Franca. Disponível em: $<$ http://www.baleiafranca.org.br>. Acesso em: 03 dez. 2013.

BRAGA, B. et al. Introdução à Engenharia Ambiental: $O$ desafio do desenvolvimento sustentável. 2 ${ }^{a}$. ed. São Paulo: Editora Pearson Education do Brasil, 2006.

BRASIL. Plano Nacional de Educação. Brasília, Câmara dos Deputados, 2000. Disponível em: <http://www.portal.mec.gov.br/arquivos/pdf/pne.pdf >. Acesso em: 19 mar. 2013.

BRASIL. Secretaria de Educação Média e Tecnológica. PCN+ Ensino Médio: orientações educacionais complementares aos Parâmetros Curriculares Nacionais. Ciências da Natureza, Matemática e suas Tecnologias. Brasília, MEC, $\quad$ SEMTEC, 2004. Disponível em: $<$ http://www.portal.mec.gov.br/seb/arquivos/pdf/CienciasNatureza.pdf>. Acesso em: 27 fev. 2013.

CASTELLS, M. O poder da Identidade: A Era da Informação: economia, sociedade e cultura. v. 2, 2ª ed. São Paulo: Editora Paz e Terra, 2000.

CASTRO, J.F.M.; DINIZ, A.M.A.; BARROS, G.F. Interseções Geográficas: uma análise da cartografia filatélica brasileira. Sociedade \& Natureza, Uberlândia, v. 19, n. 2, p. 153-169, 2007.

Revbea, São Paulo, V. 10, № 1: 97-117, 2015. 
CONTRERAS, J. Autonomia de professores. São Paulo: Editora Cortez, 2002.

CORREIOS. Reciclagem - Artesanato. Revista Correio Filatélico, Brasília, Ano 26, n. 191, Janeiro/Junho, 2003.

ECT. Empresa Brasileira de Correios e Telégrafos. Disponível em: <http://www.correios.com.br>. Acesso em: 22 fev. 2013.

FERREIRA, A.B.H. Novo Aurélio Século XXI: o dicionário da língua portuguesa. 3ª . ed. Rio de Janeiro: Editora Nova Fronteira, 1999.

FONSECA, M.L.T.A. Selos postais: fonte de inovação, arte e beleza promovendo a comunicação. Correio Filatélico, Brasília, v. 210, p. 24-25, 2008.

LEFF, E. Epistemologia Ambiental. 3ª . ed. São Paulo: Editora Cortez, 2002.

MEYER, R.H. Catálogo de Selos do Brasil 2013. 58ª . Edição, São Paulo: Editora RHM Ltda., 2013.

MICOTTI, M.C. O ensino e as propostas pedagógicas. In: BICUDO, M.A.V. (org.). Pesquisa em Educação Matemática: concepções e perspectivas. São Paulo: Editora UNESP, p. 153-168, 1999.

SALCEDO, D.A.; GOMES, I.M.A.M. A visibilidade da ciência nos selos postais comemorativos. Revista da Associação Nacional dos Programas de PósGraduação em Comunicação (E-Compós). Brasília, v. 12, n. 1, p. 1-16, Janeiro/Abril, 2009.

SALCEDO, D.A. A ciência nos selos postais comemorativos brasileiros. Recife: Editora Universitária da UFPE, 2010. 